China Perspectives

$2010 / 1 \mid 2010$

Independent Chinese Cinema: Filming in the "Space of the People"

\title{
What Remains is Silence
}

Jia Zhangke

\section{OpenEdition}

\section{Journals}

Electronic version

URL: http://journals.openedition.org/chinaperspectives/5059

DOI: 10.4000/chinaperspectives.5059

ISSN: 1996-4617

Publisher

Centre d'étude français sur la Chine contemporaine

\section{Printed version}

Date of publication: 21 April 2010

ISSN: 2070-3449

\section{Electronic reference}

Jia Zhangke, «What Remains is Silence », China Perspectives [Online], 2010/1 | 2010, Online since 01 April 2013, connection on 28 October 2019. URL : http://journals.openedition.org/chinaperspectives/ 5059 ; DOI : 10.4000/chinaperspectives.5059

(c) All rights reserved 
C

\section{What Remains is Silence}

IA ZHANGKE

$\mathrm{M}$ y hometown of Fenyang, in Shanxi, is a county town, quite small, with a strong rural flavour. Every summer, I would help my classmates with the wheat harvest. When you reached the edge of a field at the crack of dawn, someone would hand you a sickle, and pointing to the vast stretch of gold reaching farther than the eye could see, they would say: this part is yours.

At such times, human beings seem extraordinarily insignificant; surrounded by waves of wheat as far as you could see, people were just small black specks. At sunset, when with great effort we straightened our long-bent backs and wiped away our sweat, we would turn our eyes afar. In the distance, against the sunlight, the chimneys of the diesel engine factory proudly billowed white smoke. This is when I understood why everyone wanted to enter the factory and become a worker.

"Working the earth" is arduous: these are heartfelt words. But at that time, although factory workers were also labourers, they were on speaking terms with machines, they had skills, their food was supplied, they had welfare, they were, after all, the "leading class."

There were not many factories in the county at the time: the 300 or 400 -worker diesel engine factory, and the 100 or 200-worker machinery factory were considered large. At the end of the 1970s, in the county town, when anyone's child was able to enter the factory as a worker, this was considered a glorious event for the whole family, because it meant a stable monthly wage; it meant distribution of tea leaves and white sugar in the summer, and a heating subsidy in the winter. It also meant that all members of the family could use the factory's shower room to wash, and each month there would be a distribution of gloves and bars of soap. And we children could use expired, fake tickets to follow our big brothers and sisters and sneak into the workers' club to watch Zorro. Being a worker also had the hardship of night shifts, but on your way home in the morning you could tear off some cotton yarn and tie it under the seat to scrub your bicycle. You could grind a few stainless steel handles for your family members, or a vegetable knife, or slip a roll of fuse-wire into your pocket for your electricity meter.

The idea of the factory as home made everyone forget about the distinction between public and private, and be happy in doing so. The factory's subsidised housing, the unshakable pension payments to come, represented not only material benefits, but the inner pride of an entire class.

But is anything ever unshakable in this world?

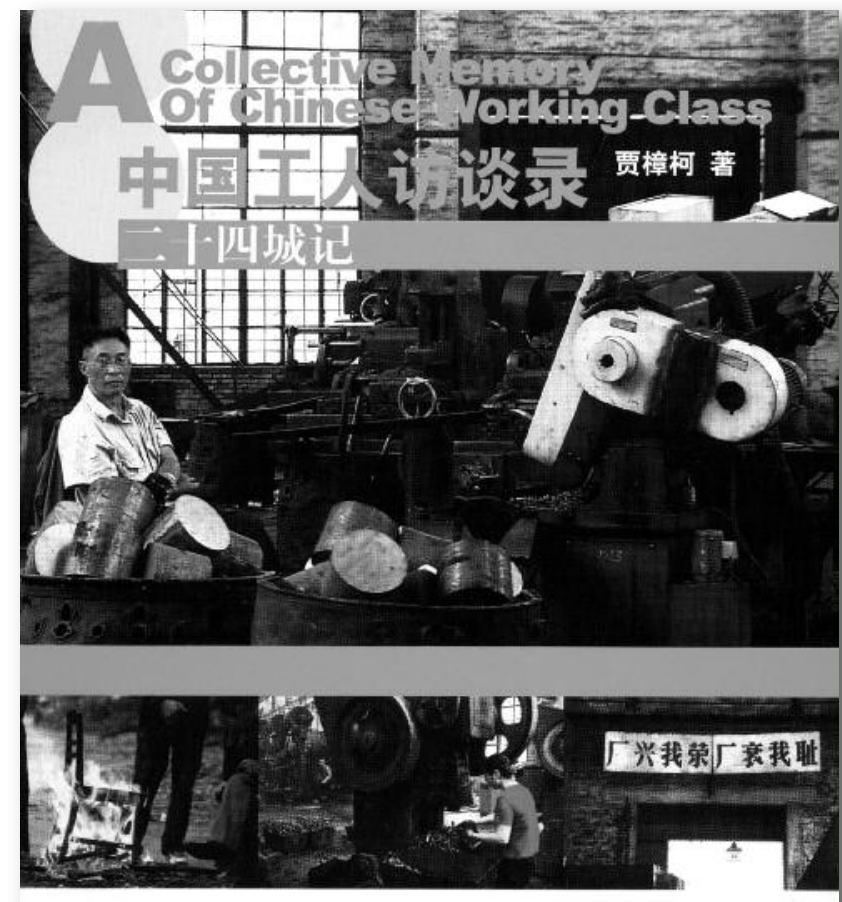

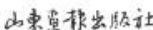

Jia Zhangke, Zhongguo gongren fangtanlu. A Collective Memory of Chinese Working Class, 2009.

When I was in my second year of high school, as the diesel engine factory was hiring, several of my classmates left school to become workers in the factory. At that time, in the eighties, to enter life quickly, to earn a stable salary, to enter the walls of the diesel engine factory where there was a basketball court with floodlights, was a prospect that made many students envious. But by the middle of the nineties, when I was still studying in Beijing, suddenly all of these former classmates were laid off. The factory was being reformed, work stopped, and these young people of only 25 or 26 were given a basic subsidy of 100 or 200 yuan and set adrift in society, leaving them in the prime of their physical strength with nothing to do.

One winter when I returned home, I saw an old classmate and several of his shift colleagues from the factory carrying 
Two scenes from Jia Zhangke's 24 City: the former topsecret Factory 420 owned by the Chengfa Corporation (top) is sold to China Resources Land (bottom). (C) Xstream pictures

coal for their families. At that time very few people in the county town had central heating, and every family had to burn coal to pass the winter. When a truck would dump several tons of coal on the street, these boys would help carry the coal from the street to the coal storerooms. Carrying a truckload of coal only earned them 10 or 20 yuan divided among three or four people, but what else could they do? Some people went out selling clothes, some became guards, some stayed at home and played mah-jongg and went on to open family gambling parlours. Others became criminals, appeared on wanted lists, fled to foreign lands, and remain at large to the present day.

I have not lived in a factory for a single day, nor have I ever asked for a single meal from inside the system, but I deeply understand the aftershocks entailed by the closing-down of the state-owned factories, and the psychological downgrading of the workers, the former leading class in society, who were marginalised to the point of being left to drift around doing odd jobs. That time, my laid-off classmates said to me: Our situation is far worse than if we were farmers. Farmers still have land, they still have four seasons of crops a year, at sowing time they still have hopes of a harvest. But the workers in the midst of this crisis are probably really like in the Internationale: "without anything."

Around the year 2000, I really wanted to make a film about state-owned factories, about the transformation of Chinese society from a planned economy to a market economy, about the situation of workers in the transformation. I wrote a script called "The Factory Gate." When the Lumière brothers invented film, in the first film they shot they set up their camera in front of the gates of the Renault car factory and filmed the workers going to and coming from work. Therefore, in my industry, the earliest characters to appear on the silver screen were labourers. This is a great tradition on two levels: firstly, the beginnings of film are rooted in a documentary aesthetics; secondly, the first time mankind used a camera to confront the world we live in, it focused on ordinary labourers. In the history of cinema, there are countless films on this topic that have stimulated me endlessly, such as The Bicycle Thief.

After finishing the script, I began to hesitate. The script was about two young people who entered a factory the same year, worked under the same master, became model workers in the same year, fell in love in the same year, whose children were born one after the other, who were laid off the same year, and who were left idle sitting in their dormitories playing mah-jongg and getting drunk. Little by little, their children grew older, and the two families decided to go into
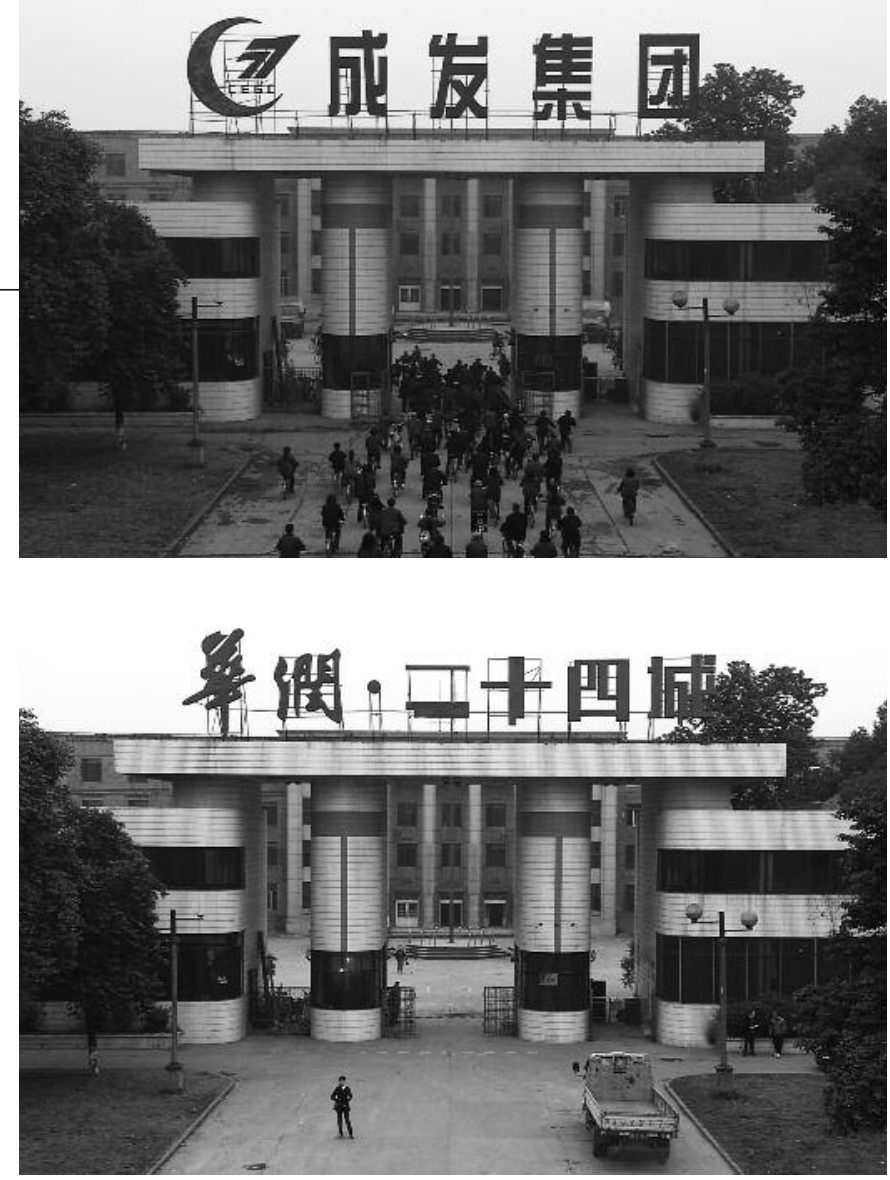

business together. They set up a clothing stall in the market and ran this small business together from early morning until late at night. As time went by, however, money problems made the harmonious relationship between the two families turn to suspicion. After I finished the script, I was satisfied for a few days. But when I thought about it with a cooler head, I asked myself what the main topic of the film could be, apart from the problem of different social levels as portrayed in the financial difficulties experienced by the workers. What else was there? I thought to myself that for a group such as workers, the experience of their existence within the system must hold some additional possibilities. I locked this script in a drawer and did not take it back out. One day at the end of 2006, I heard on the news that a factory in Chengdu employing 30,000 workers and sustaining 100,000 family members, the Chengfa Corporation (also known as Factory 420), was handing its assets over to China Resources Land (Huarun). In one year, the entire complex loaded with the lifetime memories of its 30,000 employees and 100,000 dependents would, like the smoke of a bomb, be reduced to ashes scattered in the wind, and a modern development would rise from the ground. The momentous transformation from a state-owned, top-secret factory to a commercial development was presented as the fate of the land, but what of the life and death, the rise and fall in fortunes, and the memories of countless workers? Where would these memories be placed?

This news report made me aware of the fact that the industrial memories of 50 years of the New China needed to be confronted. To make the country rich and strong, and ensure 
the happiness of its individuals, we had chosen the system of a planned economy, but what was the price we paid for this experiment over those 50 years? Those countless individuals who were at last to leave the factory, and alone in the world, to once again search for their selves, emerged from behind the news story. I suddenly felt this was a gigantic allegory. From the change in land use, from the planned economy to the market economy, from collectivism to the individual, this was a story about the system, a story about the collective memory of all Chinese people. Without hesitation, I flew to Chengdu, walked back and forth all around this factory, and decided to start shooting a new film.

As soon as I arrived in Chengdu, while leaving the airport, I could see advertisement boards under neon lights proclaiming: Chengdu, a city you will not want to leave once you've been there. What people always say about Chengdu is that prices are cheap, women are beautiful, private life can be decadent, and the rhythm is slow.

When I reached the location of the factory at Caoqiaozi, while I was walking all around factory 420 , I saw nothing in the least surprising. Along the Second Ring Road cast in cold concrete, on one side were the factory premises surrounded by an enclosing wall, which required a worker's ID for entry. On the other side was a more worldly setting: row after row of six-storey buildings made up the workers' living quarters, where people came and went, small stores rebuilt at the foot of the grey six-storey buildings, cooked food sellers, hairdressers, mah-jongg parlours. There were wedding photographers and undertakers, karaoke bars and tailor's stalls. Being born, growing old, and dying: all could be accomplished within this compound. In the afternoon, after 3 o'clock, when the sunlight gradually became gentler, people began to come to life and assemble along the broad paths of the compound, 40-something-year-olds, neither young nor old, mixed with older, entirely white-haired people, and sat down at the side of the path to begin a game of mah-jongg as if unconcerned by everything around them. The great upheavals of human existence were all summed up in the clicking sound of the mah-jongg tiles. Those hands that had held screwdrivers, those eyes that had unblinkingly scrutinised lathes, those silhouettes that had darted in and out of libraries and laboratories, now gathered along the paths, whistling around the mah-jongg games. Sometimes they would lift their heads to look at this visitor among them, then they would turn their entire attention back to the playing table.

As I made my way through the compound, I seemed to be walking through a motionless world. Not far away, the city centre was ablaze with light: Gucci, Armani, all sorts of name-brand shops had risen from the ground; Chengdu now had China's largest LV retail shop. But here in the workers' living area, the wins and losses on the playing table were always between 1 and 2 yuan. As evening fell, people went home one by one, and I wondered how much disquiet might be hidden inside this peaceful compound.

I decided to shoot a documentary, to get close to the faces of those old men, and to try to understand the words buried deep in their hearts. With the help of the Chengdu Business newspaper, we published advertisements for several days running, looking for workers willing to talk about their experience at the factory. Every afternoon I manned the hotline, and when the set time approached, those red telephones began to ring on all sides, and in the general confusion I tried to answer them one by one. In many cases, as soon as a call came through, the caller hardly said a few sentences before choking with sobs. Listening to the receiver, I could clearly make out that the caller was speaking from a quiet room. I could imagine that his wife was perhaps outside playing mah-jongg, or maybe his children were in a classroom cramming for their university entrance exams. And he, a lonely middle-aged man sitting alone in his apartment, having taken the telephone and dialled a number, was finally willing to speak about the worries he had held in his mind for so long.

These workers were just like many other Chinese people: when they left the factory, they still had a family their lives fit into. Within this circle, each of them tried their best to safeguard the family's happiness; especially in the presence of young children they would never knit a brow, and they had never let their worries or the pressure that kept them awake at night alter the family atmosphere. Each family still had happy laughter and cheerful voices around the dinner table, and one day passed peacefully after another with discussions of developments in the previous night's television drama. But when no-one else was there, they had shed tears, they had stories they could not tell. I promptly jotted down the names and contact details of these workers who wanted to tell their stories, and then I began the interviews.

When I entered the workers' homes, it was like returning to the late seventies or the early eighties. Almost all of the apartments were decorated identically: black concrete floor, a yellow double bed, a cupboard, a hanging closet, a sofa, a pair of badminton rackets hanging crossed on the wall, and a spotless white shuttlecock suspended from a nail. All material objects were frozen in the 1980s. The only objects exuding a contemporary air were the photographs of children 
wearing Nike sneakers and sporting blonde-dyed hairstyles the next generation of workers. They smiled at us from the photos without worries or concerns.

When my camera confronted these workers, what they talked about in a passionate flow was almost always other people. I kept questioning them closely: What were you doing at that time? Almost all the workers would answer: Don't ask about me, I'm quite ordinary, I have no story. The changes brought about in an individual by 50 years of collective living are not so easy to reverse. In the past, each worker believed that he existed within a group, that he was part of a collective, a screw in the machine. And today, now that they no longer need to wear the same uniform as thousands or tens of thousands of their colleagues, or pour into the factory gates at the same time as the others, now that they are sitting in their own living room and talking about their own lives, each of them is still a living worker. Getting them to talk about themselves is difficult, which makes me realise how deeply the bygone collective life influenced generation after generation of Chinese people.

Each time as the interview drew to a close, it was followed by a long period of silence. In this book, the black characters on white paper make up sentence after sentence of the real flow of life. I keep wondering, however, how many startling memories remain concealed in what is left after the interview, when the workers stop talking and remain silent. Perhaps those silences are the most important.

I am convinced that, when reading this book, everyone will also be able to see these stretches of silence.

Preface to A Collective Memory of the Chinese Working Class (Zhongguo gongren fangtanlu), 2009.

\section{- Translated by Sebastian Veg}

